\title{
THE AREAS AND TENSILE PROPERTIES OF DEFORMED CONCRETE-REINFORCEMENT BARS
}

\author{
By A. H. Stang, L. R. Sweetman, and C. Gough
}

\section{ABSTRACT}

In order to compute the yield point and tensile strength of a deformed reinforcement bar from tensile tests, the crosss-section area must be known. Four practical methods of measuring this area have been studied. The determination of the weight and length of a bar (assuming a density of $0.2833 \mathrm{lb} . / \mathrm{in} . .^{3}$ ) and the measurement of the volume of liquid displaced by a bar of known length gave results about ten times as consistent as those obtained with a micrometer or a planimeter. The first method is considered the most practical.

Specifications for deformed bars permit the tests of bars which have been machined to a cylindrical cross section. Data are lacking as to the comparative tensile properties of machined and unmachined specimens. Tensile tests were therefore made on bars having the original lugs, bars from which the lugs had been filed and bars which had been machined to a cylindrical cross section. The results of these tests showed that the yield point and tensile strength were increased slightly by filing and more by machining, but that the differences were too small to warrant the cost of machining the specimens.

\section{CONTENTS}

I. Scope and purpose of the tests

II. The specimens

III. Determination of area

1. Weight-length method.

2. Immersion method

3. Micrometer method

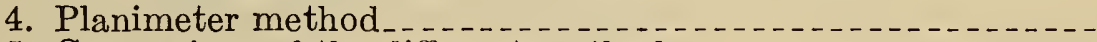

5. Comparison of the different methods

IV. The tensile tests

2. Calculation of results

3. Average results $\ldots$

4. The effect of filing off the lugs on the tensile strength

5. Comparison of tensile properties of unmachined and of machined bars

6. Determining whether a specimen conforms to the require-

V. Conclusions ments of the specification

\section{SCOPE AND PURPOSE OF THE TESTS}

Specifications ${ }^{1}$ for deformed concrete-reinforcement bars list limiting values of the stress (lbs./in..$^{2}$ ) at the yield point and the tensile strength of the bars. When reinforcing bars are tested the load in pounds at the yield point and the maximum are observed. The stresses are then computed by dividing the load by the original crosssectional area of the bar and compared with the values given in the specification.

1 United States Government master specification for bars, reinforcement, concrete, Federal Specifications Board Specification No. 350a. American Society for Testing Materials standard specifications for billetsteel concrete reinforcement bars, A. S. T. M. designation: A-15-13 and standard specifications for rail-steel concrete reinforcement bars, A. S. T. M. designation: A-16-14; A. S. T. M. standards, 1930, Pt. I, Metals, pp. 131 and 135 , respectively. 
The specifications are drawn up for the purpose of insuring that the bars shall have adequate strength, that they shall be made of a suitable quality of material, and, in addition, that the purchaser shall not be required to pay for an undue amount of overweight in delivery. The insuring of adequate strength does not require the specification of the "yield point" or "tensile strength" of the material in the bars. This purpose would be equally well, if not better, served by making use of the principles of specifications already applied to manila and wire rope, specifying for each nominal size a "minimum yield load" and a "minimum tensile load." That, in fact, is the form in which the designer will use the specified values, regardless of the particular manner in which they are expressed in the specifications.

\section{THE SPECIMENS}

Deformed bars used in this country vary in size from $1 / 4$ to $1 \frac{1}{4}$ inches. One-half inch and 1-inch bars, both round and square, were selected for these tests in which four types of deformation and three grades of steel were used. (See Table 1.) The rail steel bars were donated by the Buffalo Steel Co. The other bars were purchased from commercial stock.

Twenty-four bars were used in the tests. Beginning at one end of a bar, 12 test specimens were cut in sequence, A1, B1, C1, D1; $\mathrm{A} 2, \mathrm{~B} 2, \mathrm{C} 2, \mathrm{D} 2 ; \mathrm{A} 3, \mathrm{~B} 3, \mathrm{C} 3, \mathrm{D} 3$. The A specimens were 12 inches long, the others 20 inches. They were used as follows:

Type A, for area and density determination.

Type B, for tensile test, as received.

Type C, for tensile test after the lugs had been filed, by hand, from the middle 9-inch length.

TABLE 1.-The bars, description and density

\begin{tabular}{|c|c|c|c|c|}
\hline Type of deformation & Grade of steel & Size & Shape & Density \\
\hline Corrugated. & Intermediate, billet_... & $\left\{\begin{array}{r}\text { Inch } \\
1 / 2 \\
1 / 2 \\
1^{1 / 2}\end{array}\right.$ & $\begin{array}{l}\text { Round } \\
\text { Square-. } \\
\text { Round.-. }\end{array}$ & $\begin{array}{r}\text { Lbs./in. } 3 \\
0.2825 \\
.2826 \\
.2827\end{array}$ \\
\hline Diamond..... & ......do_... & $\begin{array}{l}1 / 2 \\
1^{1 / 2} \\
1\end{array}$ & $\begin{array}{l}\text { Round } \\
\text { Square- } \\
\text { Round } \\
\text { Square-....... }\end{array}$ & $\begin{array}{l}.2824 \\
.2825 \\
.2823 \\
.227\end{array}$ \\
\hline 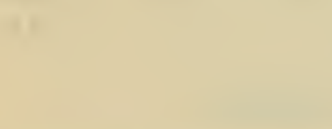 & (Structural, billet.... & $\begin{array}{l}1 / 2 \\
1^{1 / 2} \\
1\end{array}$ & $\begin{array}{l}\text { Round } \\
\text { Square-... } \\
\text { Round } \\
\text { Square }\end{array}$ & $\begin{array}{l}.2827 \\
.2826 \\
.2285 \\
.2826\end{array}$ \\
\hline Havemeyer & Intermediate, billet.. & $\left\{\begin{array}{l}\frac{1 / 2}{1 / 2} \\
1^{1 / 2}\end{array}\right.$ & 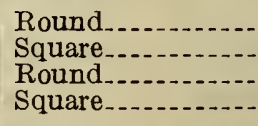 & $\begin{array}{l}.2823 \\
.2822 \\
.2822 \\
.2827\end{array}$ \\
\hline 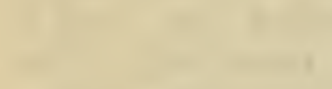 & Hard, billet....... & $\left\{\begin{array}{l}1 / 2 \\
1^{1 / 2}\end{array}\right.$ & $\begin{array}{l}\text { Round } \\
\text { Square-- } \\
\text { Round-- } \\
\text { Sound }\end{array}$ & $\begin{array}{l}.2824 \\
.2827 \\
.2825 \\
2027\end{array}$ \\
\hline Rail ..... & Hard, rail........ & $\left\{\begin{array}{l}1 / 2 \\
1^{1 / 2} \\
1\end{array}\right.$ & 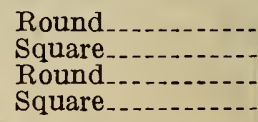 & $\begin{array}{l}.2820 \\
.2823 \\
.2824 \\
.2825\end{array}$ \\
\hline
\end{tabular}

Type $\mathrm{D}$, for tensile test after having been machined for the middle 9 -inch length to the largest cylindrical section possible with removal of all scale. 


\section{DETERMINATION OF AREA}

The area determinations by the different methods were made only on the type A specimens of the rail steel bars. These specimens had relatively small deformations and were more regular in cross section than some of the other bars.

\section{WEIGHT-LENGTH METHOD}

By this method the area generally is calculated from the weight of a measured length of the bar on the assumption that a steel bar 1 square inch in section and 1 foot long weighs 3.400 pounds, or $0.2833 \mathrm{lb}$./in. ${ }^{3}$ This value for the density is given in all American handbooks. To check the accuracy of this value, the density of one specimen of each type of deformation, grade of steel, and size was determined by the capacity and density section of the bureau. These densities, given in Table 1, are all within one-half of 1 per cent of the nominal density of $0.2833 \mathrm{lb} . / \mathrm{in}^{3}{ }^{3}$ The average density, 0.2825 lb./in. ${ }^{3}$, is less than 0.3 per cent from the nominal value.

The weight-length method is obviously an indirect volume measurement and the areas obtained represent average rather than minimum cross sections.

For this investigation each of three observers measured the length of the bars with a steel scale graduated to 0.01 inch and weighed them on an equal arm balance to the nearest 0.001 pound. Areas were then calculated by the following formula

where

$$
A=\frac{W}{\rho L}
$$

$A$ is the area, square inch.

$W$ is the weight, pound.

$L$ is the length, inch.

$\rho$ is the density, pounds per cubic inch.

The areas calculated by this method are given in Table 2. This table also lists the deviation of each observation from the average.

\section{IMMERSION METHOD}

For this method the specimens were immersed in denatured alcohol contained in a cylindrical glass graduate and the areas given in Table 2 were computed by the formula

where

$$
A=\frac{V_{1}-V}{16.39 L}
$$

$A$ is the cross-sectional area of the specimen, square inch.

$V$ is the graduate reading before the specimen is immersed, cubic centimeter.

$V_{1}$ is the graduate reading after the specimen is immersed, cubic centimeter, and

$L$ is the length of the specimen.

The length, $L$, was determined in the same way as for the weightlength method. This method has been recommended by Scheirer. ${ }^{2}$

${ }^{2}$ Accurate Method for Determining Actual Areas for Deformed Steel Reinforcing Bars, M. K. Scheirer, Concrete, vol. 33 , p. 24, September, 1928. 
TABLE 2.-Cross-sectional area of deformed bars

[Deformed rail steel concrete-reinforcement bars, type A specimens]

\begin{tabular}{|c|c|c|c|c|c|c|c|c|c|c|c|}
\hline \multirow{2}{*}{$\begin{array}{l}\text { Nomi- } \\
\text { nal } \\
\text { size } \\
\text { (inch) }\end{array}$} & \multirow{2}{*}{ Shape } & \multirow{2}{*}{$\begin{array}{l}\text { Speci- } \\
\text { men } \\
\text { No. }\end{array}$} & \multirow{2}{*}{ Observer } & \multicolumn{2}{|c|}{$\begin{array}{l}\text { Weight-length } \\
\text { method }\end{array}$} & \multicolumn{2}{|c|}{$\begin{array}{l}\text { Immersion } \\
\text { method }\end{array}$} & \multicolumn{2}{|c|}{$\begin{array}{l}\text { Micrometer } \\
\text { method }\end{array}$} & \multicolumn{2}{|c|}{$\begin{array}{l}\text { Planimeter } \\
\text { method }\end{array}$} \\
\hline & & & & Area & $\begin{array}{l}\text { Devi- } \\
\text { ation }\end{array}$ & Area & $\begin{array}{l}\text { Devi- } \\
\text { ation }\end{array}$ & Area & $\begin{array}{l}\text { Devi- } \\
\text { ation }\end{array}$ & Area & $\begin{array}{l}\text { Devi- } \\
\text { ation }\end{array}$ \\
\hline \multirow[t]{2}{*}{$1 / 2 \ldots$} & \multirow[t]{2}{*}{ Round - } & \multirow[t]{2}{*}{1} & \multirow{2}{*}{ A verage } & $\begin{array}{l}\text { Square } \\
\text { inch } \\
0.1904 \\
.1899 \\
.1903\end{array}$ & $\begin{array}{c}\text { Per } \\
\text { cent } \\
0.11 \\
.16 \\
.05\end{array}$ & $\begin{array}{l}\text { Square } \\
\text { inch } \\
0.1898 \\
.1898 \\
.1900\end{array}$ & $\begin{array}{l}\text { Per } \\
\text { cent } \\
0.05 \\
.05 \\
.05\end{array}$ & $\begin{array}{l}\text { Square } \\
\text { inch } \\
0.1901 \\
.1855 \\
.1787\end{array}$ & $\begin{array}{c}\text { Per } \\
\text { cent } \\
2.87 \\
.38 \\
3.30\end{array}$ & $\left|\begin{array}{l}\text { Square } \\
\text { inch } \\
0.183 \\
.180 \\
.177\end{array}\right|$ & $\begin{array}{l}\text { Per } \\
\text { cent } \\
1.67 \\
.00 \\
1.67\end{array}$ \\
\hline & & & & .1902 & -........ & .1899 & $\ldots \ldots$ & .1848 & -...- & .1800 & $\cdots$ \\
\hline \multirow[t]{2}{*}{$1 / 2 \ldots$} & \multirow[t]{2}{*}{ _._do_... } & \multirow[t]{2}{*}{2} & $\begin{array}{l}1 . \\
2 .- \\
3-\end{array}$ & $\begin{array}{l}.1907 \\
.1902 \\
.1904\end{array}$ & $\begin{array}{l}.16 \\
.11 \\
.00\end{array}$ & $\begin{array}{l}.1911 \\
.1910 \\
.1911\end{array}$ & $\begin{array}{l}.00 \\
.05 \\
.00\end{array}$ & $\begin{array}{l}.1909 \\
.1847 \\
.1886\end{array}$ & $\begin{array}{r}1.49 \\
1.81 \\
.27\end{array}$ & $\begin{array}{l}.190 \\
.183 \\
.187\end{array}$ & $\begin{array}{r}1.77 \\
1.98 \\
.16\end{array}$ \\
\hline & & & Avera & .1904 & $\ldots$ & .1911 & $\ldots$ & .1881 & ........... & .1867 & $\ldots$ \\
\hline \multirow[t]{2}{*}{$1 / 2 \ldots$} & \multirow[t]{2}{*}{... do } & \multirow[t]{2}{*}{3} & & $\begin{array}{l}.1886 \\
.1883 \\
.1885\end{array}$ & $\begin{array}{l}.05 \\
.11 \\
.00\end{array}$ & $\begin{array}{l}.1890 \\
.1895 \\
.1896\end{array}$ & $\begin{array}{l}.21 \\
.05 \\
.11\end{array}$ & $\begin{array}{l}.1901 \\
.1863 \\
.1825\end{array}$ & $\begin{array}{r}2.04 \\
.00 \\
2.04\end{array}$ & $\begin{array}{l}.183 \\
.177 \\
.183\end{array}$ & $\begin{array}{l}1.10 \\
2.21 \\
1.10\end{array}$ \\
\hline & & & Avera & .1885 & $-\ldots$ & .1894 & $-\cdots$ & .1863 & $-\cdots$ & .1810 & 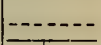 \\
\hline \multirow[t]{2}{*}{$1 / 2 \ldots$} & \multirow[t]{2}{*}{ Square.- } & \multirow[t]{2}{*}{1} & & $\begin{array}{l}.2559 \\
.2559 \\
.2561\end{array}$ & $\begin{array}{l}.04 \\
.04 \\
.04\end{array}$ & $\begin{array}{l}.2560 \\
.2568 \\
.2561\end{array}$ & $\begin{array}{l}.12 \\
.20 \\
.08\end{array}$ & $\begin{array}{l}.2549 \\
.2539 \\
.2549\end{array}$ & $\begin{array}{l}.12 \\
.27 \\
.12\end{array}$ & $\begin{array}{r}.250 \\
.243 \\
.243\end{array}$ & $\begin{array}{r}1.92 \\
. \quad .94 \\
.94\end{array}$ \\
\hline & & & Avera & .2560 & -...-... & .2563 & $\cdots$ & .2546 & $\ldots \ldots$ & .2453 & 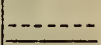 \\
\hline \multirow[t]{2}{*}{$1 / 2 \ldots$} & \multirow[t]{2}{*}{ _...do_... } & \multirow[t]{2}{*}{2} & & $\begin{array}{l}.2555 \\
.2546 \\
.2552\end{array}$ & $\begin{array}{l}.16 \\
.20 \\
.04\end{array}$ & $\begin{array}{l}.2559 \\
.2554 \\
.2551\end{array}$ & $\begin{array}{l}.16 \\
.04 \\
.16 \\
\end{array}$ & $\begin{array}{l}.2549 \\
.2539 \\
.2549 \\
\end{array}$ & $\begin{array}{l}.12 \\
.27 \\
.12\end{array}$ & $\begin{array}{r}.250 \\
.243 \\
.250 \\
\end{array}$ & $\begin{array}{r}.93 \\
1.90 \\
.93\end{array}$ \\
\hline & & & Averag & .2551 & $\ldots$ & .2555 & -....... & .2546 & ......... & .2477 & -...- \\
\hline \multirow[t]{2}{*}{$1 / 2 \ldots$} & \multirow[t]{2}{*}{ _. do _ _ _ } & \multirow[t]{2}{*}{3} & & $\begin{array}{l}.2541 \\
.2539 \\
.2541\end{array}$ & $\begin{array}{l}.04 \\
.04 \\
.04\end{array}$ & $\begin{array}{l}.2553 \\
.2550 \\
.2553\end{array}$ & $\begin{array}{l}.04 \\
.08 \\
.04\end{array}$ & $\begin{array}{l}.2529 \\
.2539 \\
.2539\end{array}$ & $\begin{array}{l}.28 \\
.12 \\
.12\end{array}$ & $\begin{array}{l}.250 \\
.250 \\
.250\end{array}$ & $\begin{array}{l}.00 \\
.00 \\
.00\end{array}$ \\
\hline & & & Average & .2540 & $\ldots$ & .2552 & .....-. & .2536 & - & .2500 & $\ldots$ \\
\hline \multirow[t]{2}{*}{1} & Round - & 1 & & $\begin{array}{l}.764 \\
.764 \\
.765\end{array}$ & $\begin{array}{l}.04 \\
.04 \\
.09\end{array}$ & $\begin{array}{l}.767 \\
.767 \\
.767\end{array}$ & $\begin{array}{l}.00 \\
.00 \\
.00\end{array}$ & $\begin{array}{l}.754 \\
.757 \\
.760\end{array}$ & $\begin{array}{l}.40 \\
.00 \\
.40\end{array}$ & $\begin{array}{l}.743 \\
.737 \\
.750\end{array}$ & $\begin{array}{l}.04 \\
.85 \\
.90\end{array}$ \\
\hline & & & Average & .7643 & -....... & .7670 & $\ldots$ & .7570 & -1 & .7433 & $\cdots$ \\
\hline 1. & -..do_. & 2 & & $\begin{array}{l}.765 \\
.765 \\
.765\end{array}$ & $\begin{array}{l}.00 \\
.00 \\
.00\end{array}$ & $\begin{array}{l}.768 \\
.768 \\
.769\end{array}$ & $\begin{array}{l}.04 \\
.04 \\
.09\end{array}$ & $\begin{array}{l}.776 \\
.762 \\
.771\end{array}$ & $\begin{array}{r}.82 \\
1.00 \\
.17\end{array}$ & $\begin{array}{l}.757 \\
.753 \\
.757\end{array}$ & $\begin{array}{l}.17 \\
.36 \\
.17\end{array}$ \\
\hline & & & A verage & .7650 & $-1-1$ & .7683 & $\cdots$ & .7697 & 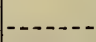 & .7557 & $\cdots$ \\
\hline & ...do . - & 3 & & $\begin{array}{l}.766 \\
.766 \\
.766\end{array}$ & $\begin{array}{l}.00 \\
.00 \\
.00\end{array}$ & $\begin{array}{r}.768 \\
.769 \\
.770\end{array}$ & $\begin{array}{l}.13 \\
.00 \\
.13\end{array}$ & $\begin{array}{l}.767 \\
.760 \\
.754\end{array}$ & $\begin{array}{l}.88 \\
.04 \\
.83\end{array}$ & $\begin{array}{r}.760 \\
.753 \\
.760\end{array}$ & $\begin{array}{l}.30 \\
.62 \\
.30\end{array}$ \\
\hline & & & A verage. & .7660 & -........... & .7690 & - & .7603 & -...... & .7577 & - . \\
\hline & Square.- & 1 & & $\begin{array}{r}.979 \\
.978 \\
.978\end{array}$ & $\begin{array}{l}.07 \\
.03 \\
.03\end{array}$ & $\begin{array}{l}.979 \\
.978 \\
.979\end{array}$ & $\begin{array}{l}.03 \\
.07 \\
.03\end{array}$ & $\begin{array}{l}.967 \\
.961 \\
.967\end{array}$ & $\begin{array}{l}.21 \\
.41 \\
.21\end{array}$ & $\begin{array}{l}.970 \\
.967 \\
.960\end{array}$ & $\begin{array}{r}.45 \\
.13 \\
.59\end{array}$ \\
\hline & & & Average & .9783 & -....- & .9787 & $\ldots$ & .9650 & -....... & .9657 & -....... \\
\hline & -...do_. & 2 & & $\begin{array}{l}.975 \\
.974 \\
.974\end{array}$ & $\begin{array}{l}.07 \\
.03 \\
.03\end{array}$ & $\begin{array}{l}.975 \\
.975 \\
.974\end{array}$ & $\begin{array}{l}.03 \\
.03 \\
.07\end{array}$ & $\begin{array}{l}.963 \\
.959 \\
.971\end{array}$ & $\begin{array}{l}.13 \\
.55 \\
.69\end{array}$ & $\begin{array}{l}.957 \\
.943 \\
.963\end{array}$ & $\begin{array}{r}.28 \\
1.18 \\
.91\end{array}$ \\
\hline & & & Average. & .9743 & $\ldots$ & .9747 & $-\ldots$ & .9643 & - & .9543 & -....... \\
\hline & do & 3 & & $\begin{array}{l}.981 \\
.981 \\
.981\end{array}$ & $\begin{array}{l}.00 \\
.00 \\
.00\end{array}$ & $\begin{array}{l}.981 \\
.981 \\
.983\end{array}$ & $\begin{array}{l}.07 \\
.07 \\
.13\end{array}$ & $\begin{array}{l}.973 \\
.967 \\
.971\end{array}$ & $\begin{array}{l}.28 \\
.34 \\
.07\end{array}$ & $\begin{array}{l}.960 \\
.960 \\
.953\end{array}$ & $\begin{array}{l}.24 \\
.24 \\
.49\end{array}$ \\
\hline & & & Average & .9810 & n-n-1 & .9817 & $-\ldots$ & .9703 & 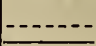 & .9577 & -...- \\
\hline & & & $\begin{array}{c}\text { Grand a } \\
\text { age }\end{array}$ & & .05 & & .07 & & .64 & & .77 \\
\hline
\end{tabular}


The bars were held by a small copper wire, the immersed volume of which was less than $1 / 20 \mathrm{~cm}^{3}$. Alcohol was used rather than water because, due to its lower surface tension, the level of the liquid in the graduate could be more accurately determined. It also wets the steel bar so that air bubbles are not trapped on the surface as with water. The calibrated graduate used with the $1 / 2$-inch bars was graduated to $0.5 \mathrm{ml}$ and that used with the 1 -inch bars to $1.0 \mathrm{ml}$. On both readings were estimated to $1 / 10 \mathrm{ml}$.

\section{MICROMETER METHOD}

The minimum areas were calculated from measurements with a micrometer caliper of the sides of the square bar or the diameter of round bars. Two measurements to the nearest 0.001 inch were taken on each side of two sides (or of two diametral planes perpendicular to each other) and the four measurements were averaged. Correction was made for the rounded corners of the square bars, the radii of these corners being measured with radius gages. The areas are given in Table 2.

\section{PLANIMETER METHOD}

The smooth end of a bar was impressed on a paper and the area of the impression measured with a polar planimeter. It is customary in some laboratories to ink the end of the bar, and force it, using a testing machine, against the paper which may be backed up with blotting paper or some other relatively soft substance. Preliminary studies with round and square machined specimens showed that this procedure gave areas smaller than the area computed from the dimensions. This difference was probably due to the soft backing: material.

The method finally adopted was as follows: The end of the bar was finished smooth, care being taken to avoid rounding the corners. This surface was inked with an inking pad, the surplus ink around the edges wiped off, and several impressions were made on buff detail paper. The weight of the specimen, 12 inches long, supplied the impressing force. The second or third impression was usually better than the first due to the smaller amount of ink on the end of the bar. This method resulted in clear cut perimeters.

The areas were measured with a Coradi polar planimeter with an arm length such that each division of the vernier amounted to 0.01 in. ${ }^{2}$. The mean of three measurements by each observer is given in Table 2.

\section{COMPARISON OF THE DIFFERENT METHODS}

The deviations given in Table 2 are measures of the variation in the areas as determined by different observers and by different methods. If the average of the deviations for one method is smaller than for another method, it is probable that the first method will give more consistent values for different observers than the second. On this basis, the weight-length method is best and then come, in order, the immersion method, the micrometer method, and finally the planimeter method.

This rating is supported by a consideration of the observational errors involved. If three sets of observations made by the weightlength method are not in error more than plus or minus 0.01 inch in 
12 inches as regards length and not more than plus or minus 0.001 pound in 0.668 pound as regards weight (1/2-inch round bar), then the average departure of an individual determination from the mean of three should never exceed 0.2 per cent. For the immersion method, with the same uncertainty as regards length and a possible error of plus or minus $0.1 \mathrm{ml}$ in $38.7 \mathrm{ml}$ in measuring the displacement, the average departure should not exceed 0.3 per cent; while in the planimeter method with an uncertainty of 0.01 in. $^{2}$ in the measurement of an area of only $0.2 \mathrm{in} .^{2}$, the average departure of three determinations from the mean may reach 4.3 per cent. While these percentages are limiting values (not the most probable average deviation) they should conform approximately in relative magnitude with the grand averages of the observed deviations in Table 2. Considering the methods in the order discussed, the computed relative magnitudes of the deviations for the three methods are $1: 1.5: 21$, while the relative magnitudes of the corresponding observed deviations are 1:1.4:15.

A. similar analysis of the micrometer method was not attempted. Deformed bars do not have simple regular sections, and the cross sectional area may vary from point to point along the bar, so that the average deviation depends more upon the location of the measuring stations on the bar than upon the precision of the micrometer readings.

Current specifications permit the deliveries of reinforcement bars one-half inch in diameter or larger which deviate not more than plus or minus 7.5 per cent from the nominal area. If the nominal area is used in the determination of yield point, tensile strength and elongation from the values observed during a tensile test, errors of this order of magnitude may be introduced in the results. If an accuracy of this order of magnitude is sufficient to insure that the material is of suitable quality without an undue percentage of rejections of borderline material, it would be simplest and most economical to require that yield points and tensile strengths for specification purposes be calculated on the basis of the nominal areas, which are used by the engineer in his design calculations.

If an accuracy of this order is not considered sufficient to insure that the material is of suitable quality without undue rejections of borderline material, the weight-length method of area measurement is undoubtedly to be preferred to any of the others. It requires no special apparatus, the measurements are easy to make, and the errors (maximum plus or minus 0.2 per cent) are much below those tolerated (plus or minus 1 per cent) in testing machines.

\section{THE TENSILE TESTS}

\section{METHOD OF TESTING}

The $1 / 2$-inch bars were tested in a testing machine having 50,000 pounds capacity and the 1-inch bars in a testing machine having a capacity of 100,000 pounds. The specimens were held with wedge grips, well lubricated with grease and graphite on the sliding surfaces. The rate of separation of the heads of both machines under no load, was 0.4 inch per minute. The yield point was determined by the drop of beam. All specimens had definite drop of beam yield points. 


\section{CALCULATION OF RESULTS}

The yield point and tensilve strength values were calculated from the test loads for the different types of tensile specimens by dividing by the area found as follows:

Type $B$ specimens tested as received.-The areas were determined by the weight-length method.

Type $C$ specimens with lugs filed off.-The specimens were weighed and their length measured. The fractional length with lugs left on was then determined from a count of the total number of original lugs and of the lugs left on. The weight of this length was determined from the calculated weight of an equal length of the corresponding A specimens. The difference between the total weight of the $\mathrm{C}$ specimen and the weight of the fractional length with lugs left on gave the weight of the fractional length from which the lugs had been filed. The area was then calculated by the weight-length method.

Type $D$ specimens, machined to a cylindrical section.-The diameter was measured to the nearest 0.001 inch with a micrometer caliper and the area calculated from this diameter.

The elongation in 8 inches was measured with dividers and a steel scale to 0.01 inch. For the few specimens which broke outside of the middle half of the gage length, the elongation was computed according to the method outlined in A. S. T. M. tentative specification, serial designation: E8-27T. ${ }^{3}$

\section{AVERAGE RESULTS}

The yield-point and tensile-strength values for the three specimens of each type from each bar were very consistent. The elongation values varied more. The greatest variation of a single value from the mean for each of the 72 groups of three specimens was less than $3 \frac{1}{2}$ per cent for the yield point values and less than $2 \frac{1}{2}$ per cent for the tensile strengths (except for one group). For 54 of the groups the maximum deviation of the elongation values was less than 5 per cent. The average results are given in Table 3 , each value for yield point, tensile strength and elongation being the average for the three similar specimens from each bar.

${ }^{3}$ Tentative Methods of Tension Testing of Metallic Materials, Proc. A. S. T. M., vol. 27, Pt. I, p. 1078. 


\begin{tabular}{|c|c|c|c|c|c|c|c|}
\hline \multirow{2}{*}{ 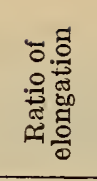 } & A.N & 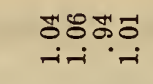 & 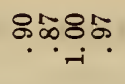 & 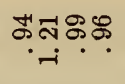 & ஜఃఃి & ţ\%: & 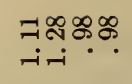 \\
\hline & $0 \not$ & 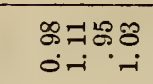 & 8효용. & 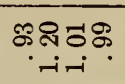 & 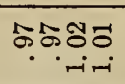 & 호 & 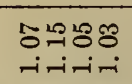 \\
\hline \multirow{3}{*}{ 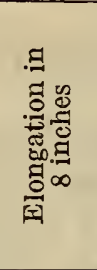 } & 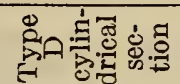 & 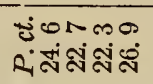 & 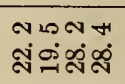 & 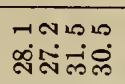 & 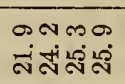 & 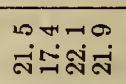 & 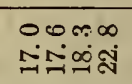 \\
\hline & : & 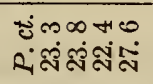 & 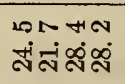 & 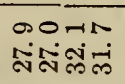 & 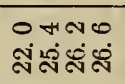 & 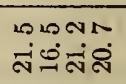 & 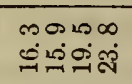 \\
\hline & 蛋 & 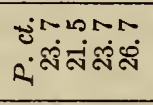 & 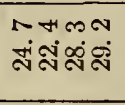 & 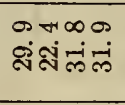 & 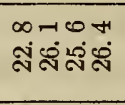 & 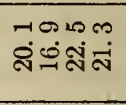 & 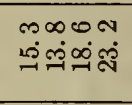 \\
\hline \multirow{2}{*}{ 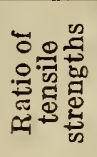 } & AII & 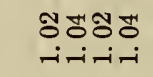 & 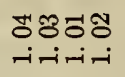 & 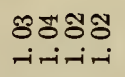 & 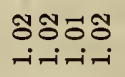 & $\begin{array}{l}588 \% 8 \\
\text { ini-i-i }\end{array}$ & 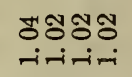 \\
\hline & $O M$ & 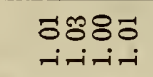 & $\begin{array}{l}8085 \\
\text { itriti-i }\end{array}$ & 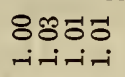 & 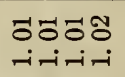 & 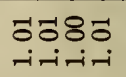 & $\begin{array}{l}8850 \\
\text { ifititi }\end{array}$ \\
\hline \multirow{3}{*}{ 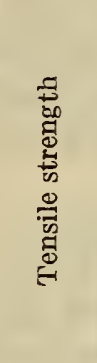 } & 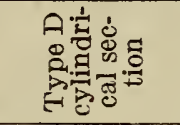 & 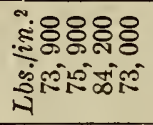 & 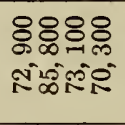 & 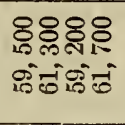 & 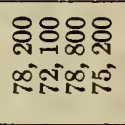 & 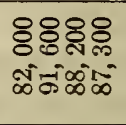 & 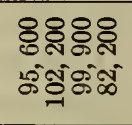 \\
\hline & 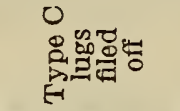 & 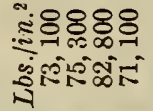 & 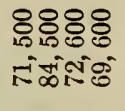 & 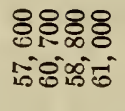 & 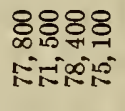 & 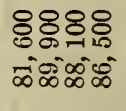 & 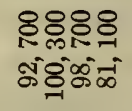 \\
\hline & 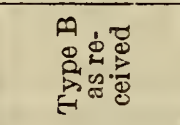 & 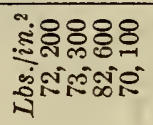 & 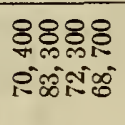 & 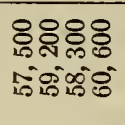 & 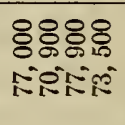 & 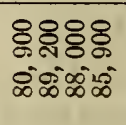 & 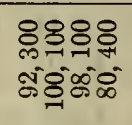 \\
\hline \multirow{2}{*}{ 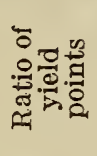 } & Alm & 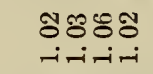 & $\begin{array}{l}8 \% 8 \% \\
\text { rimiti- }\end{array}$ & 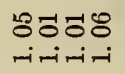 & $\begin{array}{l}8508 \\
\text { inititi }\end{array}$ & க.రిశ్ర & 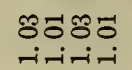 \\
\hline & Oln & 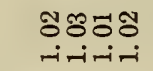 & $\begin{array}{l}\text { श8880 } \\
\text { i-i-i-i }\end{array}$ & 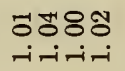 & 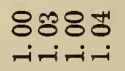 & $\begin{array}{l}80000 \\
\text { ifititi }\end{array}$ & $\begin{array}{l}0888 \\
\text { iُشi-i-i }\end{array}$ \\
\hline \multirow{3}{*}{ 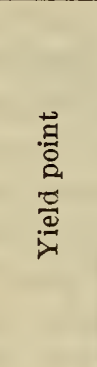 } & 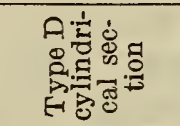 & 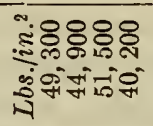 & 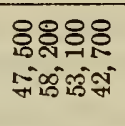 & 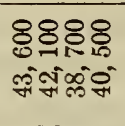 & 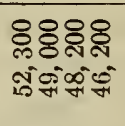 & 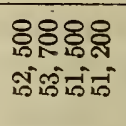 & 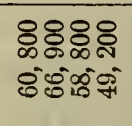 \\
\hline & 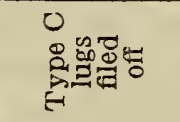 & 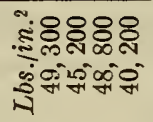 & 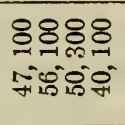 & 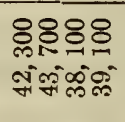 & 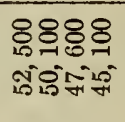 & 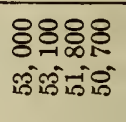 & 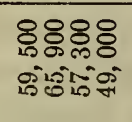 \\
\hline & 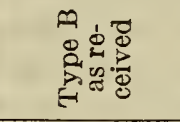 & 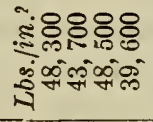 & 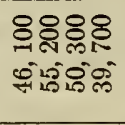 & 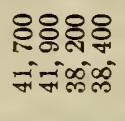 & 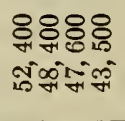 & 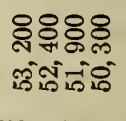 & 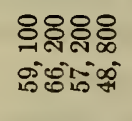 \\
\hline \multicolumn{2}{|c|}{ 趌 } & 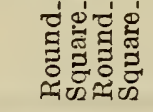 & 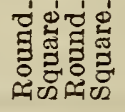 & 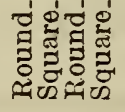 & 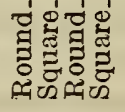 & 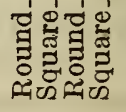 & 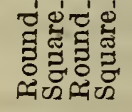 \\
\hline \multicolumn{2}{|c|}{ 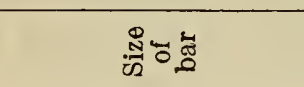 } & है & $\underbrace{-5 n^{2}-1}$ & बल & $\lambda_{-1-1}$ & $x^{2}-1$ & $A^{N}{ }^{2}$ \\
\hline \multicolumn{2}{|r|}{ 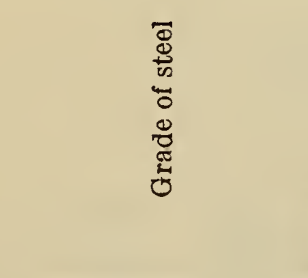 } & 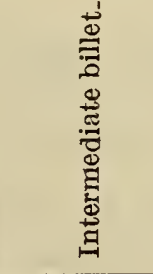 & 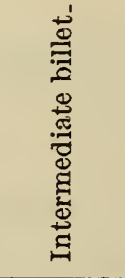 & 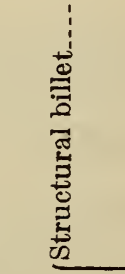 & 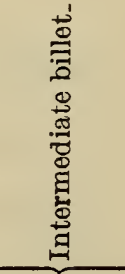 & 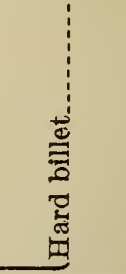 & 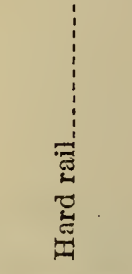 \\
\hline & 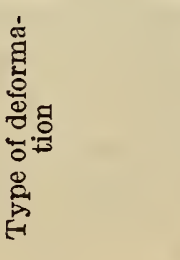 & 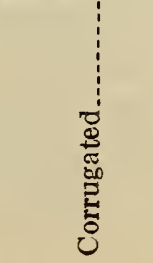 & 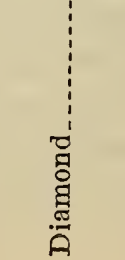 & & 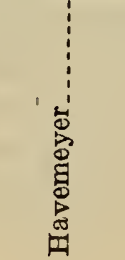 & & : \\
\hline
\end{tabular}




\section{THE EFFECT OF FILING OFF THE LUGS, ON THE TENSILE STRENGTH}

The average maximum load in pounds of the type $\mathrm{C}$ specimens with lugs filed off was less in all cases than the average maximum load in pounds of the type B specimens which were tested as received. The areas based upon weight-length measurements were also less, but Table 4 which lists the decrease in maximum load and area of the type $\mathrm{C}$ specimens with respect to the type $\mathrm{B}$ specimens shows that the decrease in area was in all cases greater than the decrease in maximum load. The lugs were therefore effective in resisting tensile forces to some extent. An example will be used to show how the relative effectiveness of the area of the lugs in tension as given in Table 4 has been calculated.

Example.-1/2-inch round bars, Havemeyer type of deformation, intermediate grade of billet steel:

\begin{tabular}{|c|c|c|c|}
\hline Type of specimen & $\begin{array}{l}\text { A verage } \\
\text { area }\end{array}$ & $\begin{array}{c}\text { A verage } \\
\text { tensile } \\
\text { load }\end{array}$ & $\begin{array}{l}\text { A verage } \\
\text { tensile } \\
\text { strength }\end{array}$ \\
\hline $\begin{array}{l}\text { B, as received } \\
\text { C, lugs filed off. }\end{array}$ & $\begin{array}{c}\text { Square inch } \\
0.1935 \\
.1880\end{array}$ & $\begin{array}{r}\text { Pounds } \\
14,910 \\
14,630\end{array}$ & $\begin{array}{c}\text { Lbs./in. }{ }^{2} \\
77,000 \\
77,800\end{array}$ \\
\hline B-C.... & .0055 & 280 & \\
\hline
\end{tabular}

Tensile strength of lug area, $\frac{280}{0.0055}=50,900 \mathrm{lbs} . /$ in. $^{2}$

$\frac{\text { Tensile strength of lug area }}{\text { Tensile strength for Type C }}=\frac{50,900}{77,800}=0.65$

It may, therefore, be concluded that the lug area of these bars was 65 per cent effective in resisting tensile stresses. Similar values for all bars are given in Table 4 . Since these values depend on small differences between relatively large numbers, the results are somewhat variable. They show, however, that the lug area of the Havemeyer and rail steel bars were more than 50 per cent effective in resisting tensile forces. These lugs were parallel to the axis of the bars. The corrugated and diamond deformations were not parallel to the axis of the bars and the lug area was less effective in resisting tensile forces than for the other types. Since, however, the lug areas in the Havemeyer bars were always much larger than in the other types of bars (see Table 4) the effectiveness of the total area in resisting tensile load was practically the same for all types of bars as shown in $\mathrm{C} / \mathrm{B}$ ratios of Table 3. 
TABLE 4.-Effect of filing off lugs on the maximum load and on the area

\begin{tabular}{|c|c|c|c|c|c|c|}
\hline 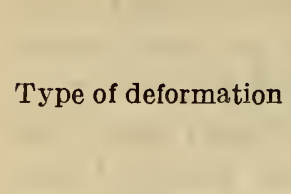 & Grade of steel & $\begin{array}{l}\text { Nom- } \\
\text { inal } \\
\text { size }\end{array}$ & Shape & $\begin{array}{c}\text { Decrease } \\
\text { in maxi- } \\
\text { mum load }\end{array}$ & $\begin{array}{l}\text { Decrease } \\
\text { in area }\end{array}$ & $\begin{array}{c}\text { Relative } \\
\text { effective- } \\
\text { ness of } \\
\text { area of } \\
\text { lugs in } \\
\text { tension }\end{array}$ \\
\hline Corrugated_. & Intermediate & $\left\{\begin{array}{c}\text { Inch } \\
1 / 2 \\
1 / 2 \\
1 \\
1\end{array}\right.$ & $\begin{array}{l}\text { Round...... } \\
\text { Square-...-. } \\
\text { Round-...-. } \\
\text { Square.-... }\end{array}$ & $\begin{array}{r}\text { Per cent } \\
0.9 \\
1.0 \\
.6 \\
.7\end{array}$ & $\begin{array}{r}\text { Per cent } \\
2.1 \\
3.7 \\
.9 \\
2.0\end{array}$ & $\begin{array}{r}\text { Per cent } \\
44 \\
27 \\
73 \\
33\end{array}$ \\
\hline Diamond . - & do & $\begin{array}{l}1 / 2 \\
1^{1 / 2} \\
1\end{array}$ & 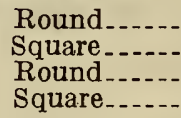 & $\begin{array}{r}.4 \\
.9 \\
.9 \\
1.1\end{array}$ & $\begin{array}{l}1.8 \\
2.4 \\
1.4 \\
2.5\end{array}$ & $\begin{array}{l}20 \\
39 \\
63 \\
44\end{array}$ \\
\hline \multirow{3}{*}{ Havemeyer. } & (Structural_. & $\begin{array}{l}1 / 2 \\
1^{1 / 2} \\
1\end{array}$ & $\begin{array}{l}\text { Round...... } \\
\text { Square-.... } \\
\text { Round } \\
\text { Square.-...-. }\end{array}$ & $\begin{array}{l}2.6 \\
6.1 \\
1.7 \\
4.4\end{array}$ & $\begin{array}{l}2.7 \\
8.3 \\
2.7 \\
5.0\end{array}$ & $\begin{array}{l}95 \\
72 \\
63 \\
88\end{array}$ \\
\hline & Intermediate & $\begin{array}{l}1 / 2 \\
1^{1 / 2} \\
1\end{array}$ & 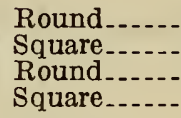 & $\begin{array}{l}1.9 \\
5.3 \\
2.4 \\
4.3\end{array}$ & $\begin{array}{l}2.8 \\
6.2 \\
2.7 \\
6.4\end{array}$ & $\begin{array}{l}65 \\
86 \\
92 \\
67\end{array}$ \\
\hline & Hard . . & $\begin{array}{l}1 / 2 \\
1^{1 / 2} \\
1\end{array}$ & $\begin{array}{l}\text { Round--.-- } \\
\text { Square--.-. } \\
\text { Round-.--- } \\
\text { Square--.-. }\end{array}$ & $\begin{array}{l}2.1 \\
5.4 \\
3.1 \\
3.6\end{array}$ & $\begin{array}{l}2.9 \\
6.1 \\
3.2 \\
4.3\end{array}$ & $\begin{array}{l}71 \\
88 \\
96 \\
85\end{array}$ \\
\hline Rail _. & -..-_do-. & $\underbrace{1 / 2} 1^{1 / 2}$ & $\begin{array}{l}\text { Round.-...- } \\
\text { Square } \\
\text { Round.-...-. } \\
\text { Square.-...- }\end{array}$ & $\begin{array}{l}1.8 \\
2.3 \\
1.0 \\
1.1\end{array}$ & $\begin{array}{l}2.2 \\
2.4 \\
1.5 \\
2.0\end{array}$ & $\begin{array}{l}80 \\
93 \\
63 \\
54\end{array}$ \\
\hline
\end{tabular}

\section{COMPARISON OF TENSILE PROPERTIES OF UNMACHINED AND OF MACHINED BARS}

Table 3 gives the average results of the tensile tests. The tensile strength of type D specimens machined to cylindrical cross section was in all cases greater than that of the type $\mathrm{C}$ specimens, with lugs filed off. The increase in average strength of the type $D$ specimens over the type B specimens was, however, in all cases less than 5 per cent.

The same general conclusions can be drawn from the yield point values although in two instances the average yield point for the type $D$ specimens was 1 per cent below the value for the type $B$ specimens.

The effect of type of specimens on the elongation was erratic. On the average, the elongation was not much affected by filing off the lugs or machining the bar. The average elongation in 8 inches was 23.7 per cent for the bars tested as received, 23.9 per cent for the bars from which the lugs had been filed and 23.7 per cent for the bars which were machined to a cylindrical cross section.

Table 3 shows that the tensile properties are not influenced by the size or shape of the bar, or by the type of deformation.

The small difference in the tensile properties of machined and unmachined specimens leads to the suggestion that the use of the expensive machined specimen be eliminated from the specifications. If the use of the original sections of deformed bars were made mandatory for tensile tests, one point of controversy would be eliminated.

The results listed in Table 3 show only two border-line cases in which specimens which failed to comply with the requirements of the specification as to yield point or tensile strength when tested as 
received, did comply when machined. These are the 1-inch square corrugated and diamond bars. For the intermediate grade of steel, the specified minimum yield point and tensile strength values are 40,000 and 70,000 lb./in. ${ }^{2}$, respectively.

\section{DETERMINING WHETHER A SPECIMEN CONFORMS TO THE RE- QUIREMENTS OF THE SPECIFICATION}

By chance, the tensile strength of the 1-inch square rail steel specimen B-3, tested as received, affords an example of the difficulties of determining whether a specimen conforms to the requirements of the specification, when no method of area determination has been specified. Table 5 gives data as to the breaking load of this bar, of the area as determined by different methods (average results from Table 2 have been used), and of the tensile strength, when computed with regard to the different areas.

In this case, the values given in Table 5 show that the tensile strength computed by the nominal area, weight-length, and immersion methods, did not conform to the requirements of the specification. The tensile strength, computed from areas determined by the micrometer and planimeter methods, did comply with the specified requirement. In border-line cases such as this, it is apparent that much confusion results and honest differences of opinion arise when the method of area determination is not specified. The necessity of specifying some method of area determination is obvious.

TABLE 5.-The tensile strength of rail steel specimen B-3, 1 inch square, tested as received

[Breaking load, $\mathbf{7 7 , 9 7 0}$ pounds]

\begin{tabular}{|c|c|c|}
\hline Method of determining area & Area & $\begin{array}{l}\text { Tensile } \\
\text { strength }\end{array}$ \\
\hline $\begin{array}{l}\text { Nominal area } \\
\text { Weight-length } \\
\text { Immersion } \\
\text { Micrometer } \\
\text { Planimeter }\end{array}$ & \begin{tabular}{|c} 
Square inch \\
1.000 \\
.9780 \\
.9767 \\
.9703 \\
.9577
\end{tabular} & $\begin{array}{r}\text { Lbs./in. }{ }^{2} \\
77,970 \\
79,700 \\
79,800 \\
80,300 \\
81,400\end{array}$ \\
\hline Specified minimum & 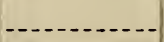 & 80,000 \\
\hline
\end{tabular}

\section{CONCLUSIONS}

1. Area determinations by different observers of deformed concrete-reinforcement bars, one-half and 1 inch in size, both round and square in section were made by four different methods. The conclusions reached as a result of this study are as follows:

(a) If specifications for concrete-reinforcing bars specify the yield point and tensile strength in pounds per square inch of the material in the bars, the method of determining the area to be used in calculating them should be definitely specified.

(b) The nominal areas which are used by the engineer in his design calculations should be used in computing yield point and tensile strength values from the test results if the accuracy of the nominal area is considered sufficient. Since current specifications permit the deliveries of reinforcement bars one-half inch in diameter or larger which deviate not more than plus or minus $71 / 2$ per cent from the nominal area, errors of this order of magnitude may be introduced in the results. 
(c) If accuracy of the order of plus or minus 7.5 per cent in the determination of yield point, tensile strength, and elongation of concrete reinforcement bars is not sufficient to insure that the material is of suitable quality, without an undue percentage of rejections of border-line material, the specifications should require the use of the weight-length method.

(d) The immersion method under ordinary laboratory conditions gives no greater accuracy than the weight-length method, and is much less easy to apply.

(e) The micrometer method applied to deformed bars gives much less accurate results than either the weight-length or the immersion method.

(f) The planimeter method is costly and time consuming. With the usual planimeters and within the usual range of sizes it gives much less accurate results than either the weight-length or the immersion method.

2. Tensile tests were made of deformed concrete-reinforcement bars, of three grades of steel, four types of deformation, one-half and 1 inch in size, both round and square in section. Each bar was tested (1) in the original condition, (2) after the lugs had been filed by hand from the middle 9-inch length, and (3) after the bars had been machined to a cylinarical cross section for the middle 9-inch length. The conclusions reached as a result of the tensile test are as follows:

(a) Removing the lugs from deformed concrete-reinforcement bars decreased slightly the load (pounds) carried by the bars at the yield point and at failure. The percentage decrease in load, however, was in no case as large as the percentage decrease in the average area as determined by the weight-length method, so that the yield point (pounds per square inch) increased from 0 to 4 per cent and the tensile strength (pounds per square inch) from 0 to 3 per cent, with no significant difference between the different types of bars.

(b) There was, however, a marked difference in the manner in which the different types of lugs contributed to the strength of the bar. The area of the Havemeyer lugs was approximately 50 per cent effective in resisting tensile stresses, while the areas of the corrugated and diamond type lugs were less effective.

(c) Machining deformed concrete-reinforcement bars to a cylindrical cross section increased the tensile strength (pounds per square inch) over the tensile strength of similar bars tested with the lugs on. The increase was, however, in no case as large as 5 per cent.

(d) The yield point (pounds per square inch) of deformed concretereinforcement bars machined to a cylindrical section was in general greater than the yield point of similar bars not machined. The maximum increase was 8 per cent.

(e) The effect of machining deformed concrete-reinforcement bars on the elongation was small and erratic. Sometimes the machined bars showed higher elongation and sometimes lower. The maximum difference for the elongation of unmachined and machined bars was less than 5 per cent in 8 inches. In the specimens tested, the difference was in no case sufficient to cause rejection of the material in the unmachined condition.

(f) These differences seem to be altogether too small to warrant the cost of machining concrete-reinforcement bars when testing under specifications.

Washington, August 1, 1932. 